ENFOQUES JURIDICOS

REVISTA MULTIDISCIPLINAR DEL CEDEGS

ISSN 26832070

Número 04

julio-diciembre 2021
Reseña: “El futuro empieza hoy”

Rebeca Elizabeth Contreras López

DOI: https://doi.org/10.25009/ej.v0i04.2575

\title{
El futuro empieza hoy
}

Recibido 17 junio 2021-Aceptado 18 junio 2021

\section{Sousa Santos, Boaventura de (2020). La cruel pedagogía del virus. (Paula Vasile, Trad.) Biblioteca Masa Crítica, Buenos Aires: CLACSO. ISBN 978-987-722-599-0}

\author{
Rebeca Elizabeth Contreras López* \\ Universidad Veracruzana. Xalapa-Veracruz, México \\ rcontreras@uv.mx
}

En este texto, Boaventura de Sousa se ocupa del impacto de la pandemia del Covid-19 en el mundo, problematiza sus consecuencias para las regiones y personas más desprotegidas. Desde su punto de vista, la crisis es producida por las condiciones del capitalismo neoliberal que han incapacitado a los Estados para responder a las emergencias, una situación que la pandemia sólo viene a agravar. Sin embargo, en esta situación se pone en evidencia que hay otras formas de vida y alternativas al hipercapitalismo.

Quedan en evidencia las bases conceptuales y políticas del autor, así establece que desde el Sur el conocimiento surge en los actos de resistencia de grupos sociales que viven la injusticia, opresión y destrucción sistemática, desde el capitalismo reinante, pero que también son los más afectados por la situación actual. El texto se organiza en cinco apartados, relativos a: El virus: todo lo que es sólido se desvanece en el aire; la trágica transparencia del virus; al sur de la cuarentena; la intensa pedagogía del virus: las primeras lecciones y, el futuro puede comenzar hoy.

En el primer apartado se establece una guía de discusión a partir de la siguiente interrogante: ¿Qué conocimiento potencial proviene de la pandemia de coronavirus? Las crisis se han venido repitiendo desde que el mundo se sometió a la lógica del sector

\footnotetext{
* Investigadora de tiempo completo del Centro de estudios sobre Derecho, Globalización y Seguridad de la Universidad Veracruzana (CEDEGS-UV). Investigadora Nacional, nivel 1. Vocal de la Cátedra Mahatma Gandhi de la Universidad Veracruzana. Profesora de posgrado de la Universidad Veracruzana y la Universidad de Xalapa.
}

unimencas werisnasu


ENFOQUES JURIDICOS

REVISTA MULTIDISCIPLINAR DEL CEDEGS

ISSN 26832070

Número 04

julio-diciembre 2021
Reseña: “El futuro empieza hoy”

Rebeca Elizabeth Contreras López

DOI: https://doi.org/10.25009/ej.v0i04.2575

financiero, por tanto, nos enfrentamos al oxímoron de la crisis permanente. Entonces, nos damos cuenta de que hay alternativas a las formas de vida actuales, que reducir el hiperconsumismo es posible. Al respecto, Boaventura afirma que se pone "en evidencia que no hay alternativas porque el sistema político democrático ha sido forzado a dejar de discutir alternativas" (p. 22).

El texto nos lleva a preguntar si la percepción de inseguridad ¿puede explicarse a partir de un enfoque de clases y referentes económicos? Porque, afirma Boaventura, cuando se cuenta con los medios y recursos para enfrentar la incertidumbre e inseguridad, ésta (por lo menos la percepción) parece minimizarse con atención médica, pólizas de seguro, compañías de seguridad, terapias o gimnasios. El virus pulverizó la seguridad de un día para otro. Paralelamente, afirma Boaventura, "la pandemia no es ciega y tiene objetivos privilegiados, pero aún así crea una conciencia de comunión planetaria, de alguna manera democrática" (p. 23). Esta crisis, tiene consecuencias negativas, sin duda, pero también algunas positivas: la caída de la contaminación es una de ellas. Además, nos conducen a la perplejidad: China ha sido uno de los países más eficientes frente a la pandemia con métodos de represión y vigilancia estricta. Significa ello que cla democracia carece de la capacidad política para atender las emergencias? La respuesta de Boaventura es que las soluciones democráticas aún tienen que imaginarse sus propias alternativas, desde la participación cívica que se produce en vecindarios y comunidades a nivel local.

Un punto sustancial en la exposición de Boaventura es considerar las sombras que crea la visibilidad. La pandemia es un momento dramático en el mundo que pone énfasis en los sistemas de salud y en las gobernanzas mundiales, muy presionadas para enfrentar la crisis; sin embargo, lo que se pasa por alto (o al menos no se atiende con suficiencia) es la extrema vulnerabilidad en que están, los ya de por sí vulnerables. Migrantes, refugiados (en el campo de Moria, Grecia, "hay un grifo de agua para 1300 personas y no hay jabón" (Sousa, 2020: 27). Ese dato por si sólo da cuenta de la emergencia de la situación. En las grandes ciudades, con economías desarrolladas, existen círculos de pobreza y necesidad (Castells lo analiza bien en "La era de la información", Vol. III, 2004). Las zonas invisibles que están cada vez más cerca de nosotros: "Quizá baste abrir la ventana”, dice Boaventura de Sousa.

La pandemia tiene diversas interpretaciones, unas más audaces que otras. Sin embargo, entre sus múltiples significados, Boaventura, visualiza distintos aspectos. En principio el capitalismo, el colonialismo y el patriarcado, como principales modos de producción se maximizan, incluso en el corazón mismo de los hasta ahora países comunistas. Estas formas de dominación actúan juntas por ello son tan dominantes. Sus dos consecuencias inobjetables son: "la concentración escandalosa de riqueza/desigualdad social extrema y la destrucción de la vida en el planeta/la inminente catástrofe ecológica" (p. 37).

Para Boaventura, el "Sur" no es un espacio geográfico, sino un espacio-tiempo político, social y cultural. Es una metáfora que se asume como expresión del injusto sufrimiento que

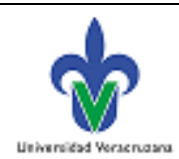

pp. $138-141$

LEVE 
ENFOQUES JURIDICOS

REVISTA MULTIDISCIPLINAR DEL CEDEGS

ISSN 26832070

Número 04

julio-diciembre 2021
Reseña: “El futuro empieza hoy”

Rebeca Elizabeth Contreras López

DOI: https://doi.org/10.25009/ej.v0i04.2575

sufren los seres humanos a raíz de las consecuencias más perversas del capitalismo y formas vejatorias de discriminación racial y sexual.

Los sectores más golpeados se presentan en las mujeres, los trabajadores precarizados informales, los vendedores ambulantes, los sin hogar, personas que viven en la calle (habitan en las ciudades, sin derecho a ellas). Como ya se señaló, los refugiados, los inmigrantes indocumentados, las poblaciones desplazadas internamente. Asimismo, los discapacitados, los ancianos. Sectores de población desechables, vulnerables, para los cuales la pandemia es un velo más de invisibilidad, frente al pánico que se apodera de todos aquellos que no estamos acostumbrados a la vulnerabilidad extrema.

Las primeras lecciones (Sousa, 2020, p. 61 y ss):

- Lección 1. El tiempo político y mediático condiciona cómo la sociedad contemporánea percibe los riesgos que corre.

- Lección 2. Las pandemias no matan tan indiscriminadamente como se cree.

- Lección 3. Como modelo social, el capitalismo no tiene futuro.

- Lección 4. La extrema derecha y la derecha hiperneoliberal han sido (con suerte) definitivamente desacreditadas.

- Lección 5. El colonialismo y el patriarcado están vivos y se fortalecen en tiempos de crisis agudas.

- Lección 6. El regreso del Estado y la comunidad, frente a la influencia omnipresente del mercado.

Finalmente, Boaventura señala que la pandemia y la necesaria cuarentena muestran, sin duda, que hay alternativas posibles, que estamos preparados para adaptarnos a nuevas formas de vida y que, cuando es necesario, la comunidad tiende al bien común.

Pese a todo, volver a la normalidad no será tan fácil para todos. Para propiciar esa reintegración se hace necesaria una nueva articulación de los procesos políticos y civilizadores, es necesario que la humanidad aprenda a actuar con una actitud más humilde ante el planeta que habita. Ello supone un giro epistemológico, cultural e ideológico que se encuentre inmerso en las decisiones sociales y políticas, que hagan viables las condiciones sociales para una vida digna de todos los habitantes del planeta.

El futuro empieza hoy. Si somos capaces de aprender lecciones y asumir convicciones de la necesidad de transformación y participación social. Si asumimos que los derechos y beneficios no están repartidos en forma equitativa. Si entendemos que los gobiernos son custodios de nuestro bienestar, obligados a velar por cada uno de los individuos que gobiernan. Si entendemos que el hiperconsumismo y la acumulación perversa del capital es un cáncer que corroe nuestra dignidad humana.

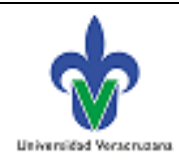

pp. $138-141$ 
ENFOQUES JURIDICOS

REVISTA MULTIDISCIPLINAR DEL CEDEGS

ISSN 26832070

Número 04

julio-diciembre 2021
Reseña: "El futuro empieza hoy"

Rebeca Elizabeth Contreras López

DOI: https://doi.org/10.25009/ej.v0i04.2575

En fin, que se trata de un libro que podrán usar para reflexionar y esperar, próximamente, mayores reflexiones de la situación en el mundo, de uno de los pensadores más lúcidos de nuestro tiempo.

Pueden obtener el texto en la biblioteca CLACSO: https://www.clacso.org/la-cruelpedagogia-del-virus-razones-para-ser-anticapitalistas/ 